Tropical Journal of Pharmaceutical Research January 2021; 20 (1): 17-22

ISSN: $1596-5996$ (print); 1596-9827 (electronic)

(C) Pharmacotherapy Group, Faculty of Pharmacy, University of Benin, Benin City, 300001 Nigeria.

\title{
Leonurusine hydrochloride promotes osteogenic differentiation via Wnt/ $\beta$-catenin pathway and expression of Runx2
}

\author{
Xiaobo Chen ${ }^{1}$, Xiaoyu Lai ${ }^{2}$, Xiaoyon Sun ${ }^{3}$, Maoyuan Wang ${ }^{1}$, Yu Cai ${ }^{1 *}$ \\ ${ }^{1}$ Department of Rehabilitation Medicine, ${ }^{2}$ Department of Orthopaedics, ${ }^{3}$ Department of Traditional Chinese Medicine, The First \\ Affiliated Hospital Of Gannan Medical University, Ganzhou, PR China
}

*For correspondence: Email: heud39@163.com

Sent for review: 21 October 2020

Revised accepted: 26 December 2020

\begin{abstract}
Purpose: To investigate the effect of leonurusine hydrochloride (LH) on osteogenic differentiation, and the involvement of Wnt/ $\beta$-catenin route and runt-associated transcription factor 2 (Runx2) in the process.

Methods: Mouse osteogenic precursor cell line MC3T3-E1 was used. The cells were assigned to control and three other groups treated with increasing doses of $L H$, i.e., $0.1,1$, and $10 \mu \mathrm{mmol} / \mathrm{L}$. Cellular differentiation was determined in the various groups with respect to mRNA expressions of alkaline phosphatase $(A L P)$, number of calcified nodules, Wnt/ß-catenin pathway-related genes, viz, 5 (LRP5), $\beta$-catenin, GSK-3$\beta$, as well as mRNA expressions of related osteogenic differentiation genes, namely. alkaline phosphatase (ALP), alpha 1 type I collagen (Col1- $\alpha)$, Run $\times 2$, and osteogenic-related transcription factor antibody (Osterix) using reverse transcription polymerase chain reaction (RT-PCR). Results: The secretion levels of ALP in cells exposed to $L H$ doses of 1 and $10 \mu \mathrm{mmol} / \mathrm{L}$ were significantly increased, relative to control values $(p<0.05)$. There were marked increases in mRNA levels of LRP5 and $\beta$-catenin in cells treated with $L H$ doses of 1 and $10 \mu \mathrm{mmol} / \mathrm{L}$ compared with the

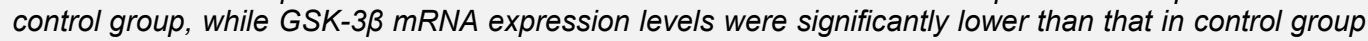
$(p<0.05)$. However, the expression levels of ALP, Col1- $\alpha$, Run $\times 2$, Osterix mRNA in cells exposed to $L H$ at doses of 1 and $10 \mu \mathrm{mmol} / \mathrm{L}$ were significantly higher than the corresponding expression levels in control cells $(p<0.05)$.

Conclusion: Leonurusine hydrochloride may promote osteogenic differentiation and bone mineralization via a mechanism involving activation of the Wnt/ $\beta$-catenin pathway and up-regulation of Run $\times 2$ expression.
\end{abstract}

Keywords: Leonurusine hydrochloride, Wnt/ß-catenin, Runx2, Osteogenic differentiation

This is an Open Access article that uses a funding model which does not charge readers or their institutions for access and distributed under the terms of the Creative Commons Attribution License (http://creativecommons.org/licenses/by/4.0) and the Budapest Open Access Initiative (http://www.budapestopenaccessinitiative.org/read), which permit unrestricted use, distribution, and reproduction in any medium, provided the original work is properly credited.

Tropical Journal of Pharmaceutical Research is indexed by Science Citation Index (SciSearch), Scopus, International Pharmaceutical Abstract, Chemical Abstracts, Embase, Index Copernicus, EBSCO, African Index Medicus, JournalSeek, Journal Citation Reports/Science Edition, Directory of Open Access Journals (DOAJ), African Journal Online, Bioline International, Open-J-Gate and Pharmacy Abstracts

\section{INTRODUCTION}

Osteoporosis comprises two major pathological types: primary osteoporosis and secondary osteoporosis. Primary osteoporosis is more prevalent than secondary osteoporosis. Reduced estrogen levels in postmenopausal women leads to increased bone resorption and decreased bone formation, which in turn leads to disorderly changes in bone microstructure, loss of calcium ions, and significant reduction in bone density and bone strength. Eventually, the incidence of 
fractures in patients is significantly increased, posing a serious threat to the elderly $[1,2]$.

Current clinical data show that osteoporotic drugs improve the patient's condition to a certain extent, but they do not enhance bone density, nor do they promote bone microstructure recovery in patients [3]. Although parathyroid hormone analogues are used for enhancing bone formation, their clinical application is limited by the fact that they may exhibit carcinogenic potential [4]. Therefore, clinical research has focused on enhancing femoral bone formation and improving osteoblast differentiation. Leonurine hydrochloride $(\mathrm{LH})$ is extracted from Leonurus sibiricus L., and it exerts multiple medicinal effects [5].

Reports indicate that it enhances contraction of uterine smooth muscle in rats and reduces the phenomenon of postpartum uterine fatigue [6]. On the other hand, $\mathrm{LH}$ reduces vascular smooth muscle contraction in cardiovascular diseases. It has been reported that wingless-type MMTV integration site family members (Wnt)/ $\beta$-catenin play important roles in the skeletal muscle and osteoblast-based bone formation, but its specific mechanism is not yet clear. Runt-related transcription factor 2 (Runx2) is an important index of bone metabolism in postmenopausal women, and its expression level is related to changes in bone density, to a certain extent [7]. However, its mechanism of action in osteoporosis is not yet understood.

Thus, this study was aimed at investigating the effect of LH on osteogenic differentiation through Wnt/ $\beta$-catenin pathway and Runx2 expression. This is expected to provide a new choice for the preventive treatment of osteoporosis.

\section{EXPERIMENTAL}

\section{Materials}

Mouse osteogenic precursor cell line MC3T3 was purchased from Shanghai Xinyu Biotechnology Co. Ltd.

\section{Main reagents and equipment}

Leonurusine hydrochloride (LH) was purchased from Linyi Azeroth Biotechnology Co. Ltd. Pancreatin EDTA was bought from Shanghai Zhongqiao Xinzhou Biotechnology Co. Ltd. Fetal bovine serum was obtained from Shenzhen Reward Life Technology Co. Ltd, while RIPA lysate was purchased from Hangzhou Haoxin Biotechnology Co. Ltd. Alkaline phosphatase staining kit was product of Jiangsu $\mathrm{KGI}$
Biotechnology Co. Ltd. Alizarin Red bought from Jiangxi Jianglan Pure Biological Reagent Co. Ltd.

Carbon dioxide $\left(\mathrm{CO}_{2}\right)$ incubator bought from Wuxi Life Biological Laboratory Equipment Co. Ltd. Optical microscope was purchased from Shanghai Jiemei Gene Medical Technology Co. Ltd. Light absorption microplate reader product of Boto Technology Bioanalysis China Representative Office. Fluorescence quantitative PCR instrument was obtained from Beijing Beijiameiyi Biological Technology Co. Ltd, while low-speed centrifuge was product of Guangzhou Best Instrument Co. Ltd.

\section{Cell passage}

Osteogenic precursor cell line MC3T3 was routinely cultured to about $85 \%$ confluence and trypsinized. When the cells appeared rounded and shrunken, the digestion process was terminated by addition of serum-containing medium, followed by centrifugation at $800 \mathrm{rpm}$ for $5 \mathrm{~min}$. The supernatant was discarded, and serum-containing medium was added to the cells at a ratio of 1:2 in a new culture flask, and placed in a constant-temperature incubator. The cells were subsequently cryopreserved and subjected to cell counting and freezing in a $-80{ }^{\circ} \mathrm{C}$ refrigerator.

Four groups of cells were used: normal control, and three groups of cells treated with increasing doses of $\mathrm{LH}$, i.e., $0.1 \mu \mathrm{mmol} / \mathrm{L}$ group, $1 \mu \mathrm{mmol} / \mathrm{L}$ group, and $10 \mu \mathrm{mmol} / \mathrm{L}$ group. Cells in the normal control groups were not treated.

The expression of ALP in each group was determined using alkaline phosphatase staining kit. The degree of calcification in each group was determined with Alizarin Red staining.

The mRNA concentrations of Wnt/ $\beta$-catenin route-associated genes in each group, i.e., LRP5, $\beta$-catenin and GSK-3 $\beta$; and mRNA expression levels of the related osteogenic differentiation genes (ALP, Col1- $\alpha$, Run $\times 2$ and osteogenic-linked transcription factor antibody, Osterix) were assayed using RT-PCR.

\section{Statistical analysis}

Data are presented as mean \pm SD. Two-group comparisons were done with $t$-test, while multiple group comparisons were done with ANOVA. All analyses were carried out using SPSS 23.0. Differences were considered statistically significant at $p<0.05$.

Trop J Pharm Res, January 2021; 20(1): 18 


\section{RESULTS}

\section{Differentiation of MC3T3-E1 cell line amongst the groups}

Alkaline phosphatase (ALP) levels were significantly higher in cells treated with $\mathrm{LH}$ at doses of 1 and $10 \mu \mathrm{mmol} / \mathrm{L}$ than in control cells $(p<0.05)$. However, there was no significant difference in ALP between cells exposed to $\mathrm{LH}$ at a dose of $0.1 \mathrm{mmol} / \mathrm{L}$ and the untreated control $(p>0.05)$. These findings are presented in Figure 1.

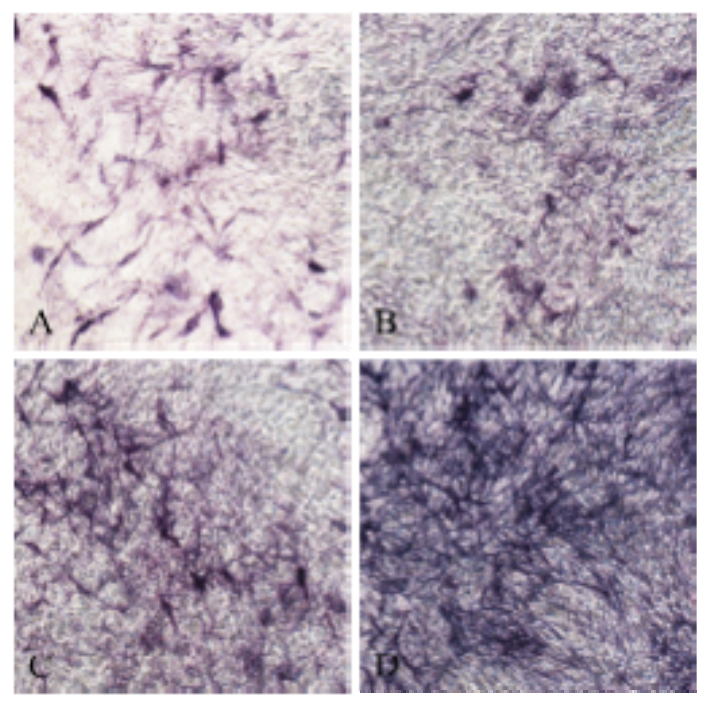

Figure 1: Comparison of ALP levels amongst the groups of MC3T3-E1 cells. A: normal control; B: LH $(0.1 \mu \mathrm{mmol} / \mathrm{L}) ; \mathrm{C}: \mathrm{LH}(1 \mu \mathrm{mmol} / \mathrm{L}) ; \mathrm{D}: \mathrm{LH}(10 \mu \mathrm{mmol} / \mathrm{L})$

\section{Degree of calcification in MC3T3-E1 cells amongst the groups}

As shown in Figure 2, the number of calcified nodules in the groups treated with $\mathrm{LH}$ doses of 1 and $10 \mu \mathrm{mmol} / \mathrm{L}$ were markedly increased, relative to control value $(p<0.05)$. However, the population of calcified nodules in the group exposed to $\mathrm{LH}$ at a dose of $0.1 \mu \mathrm{mmol} / \mathrm{L}$ did not differ markedly from that in control cells $(p>$ 0.05).

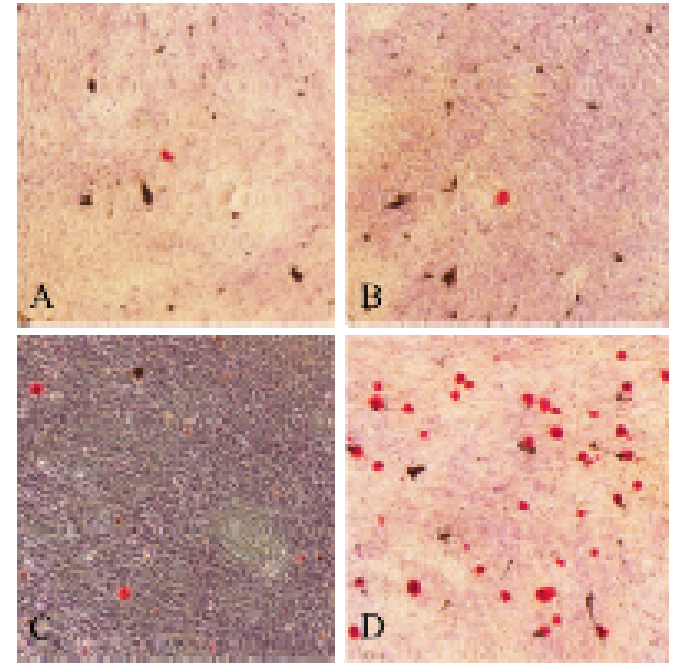

Figure 2: Comparison of the number of calcified nodules amongst the various groups of cells. A: Control; B: LH $(0.1 \mu \mathrm{mmol} / \mathrm{L}) ; \mathrm{C}: \mathrm{LH}(1 \mu \mathrm{mmol} / \mathrm{L}) ; \mathrm{D}$ : $\mathrm{LH}(10 \mu \mathrm{mmol} / \mathrm{L})$

\section{Expression levels of $\mathrm{Wnt} / \beta$-catenin route- related genes}

The expression levels of LRP5 and $\beta$-catenin mRNA were markedly higher in cells exposed to $\mathrm{LH}$ doses of 1 and $10 \mu \mathrm{mmol} / \mathrm{L}$ than in control, while GSK-3 $\beta$ levels were markedly reduced, relative to control level. However, mRNA expression levels of LRP5, $\beta$-catenin, and GSK$3 \beta$ were comparable between cells exposed to $\mathrm{LH}$ dose of $0.1 \mu \mathrm{mmol} / \mathrm{L}$ and untreated control cells $(p>0.05)$. These results are shown in Table 1.

\section{Expression levels of osteogenic differentia- tion genes}

The mRNA expression levels of ALP, Col1- $\alpha$, Run $\times 2$, Osterix in cells treated with $\mathrm{LH}$ at doses of 1 and LH $10 \mu \mathrm{mmol} / \mathrm{L}$ were significantly higher than the corresponding levels in the control group $(p<0.05)$. However, the mRNA expression levels of ALP, Col1- $\alpha$, Run $\times 2$, Osterix in cells exposed to $\mathrm{LH}$ dose of $0.1 \mu \mathrm{mmol} / \mathrm{L}$ were not statistically different from those in control group $(p>0.05)$. These results are shown in Table 2.

Table 1: Wnt/ $\beta$-catenin pathway-related gene expression levels (mean \pm SD)

\begin{tabular}{lccc}
\hline Group & LRP5 mRNA & GSK-3 $\beta$ mRNA & $\beta$-catenin mRNA \\
\hline Control & $1.01 \pm 0.01$ & $1.11 \pm 0.02$ & $1.02 \pm 0.03$ \\
LH $(0.1 \mathrm{mmol} / \mathrm{L})$ & $1.67 \pm 0.35$ & $0.99 \pm 0.02$ & $0.97 \pm 0.09$ \\
LH $(1 \mathrm{mmol} / \mathrm{L})$ & $2.56 \pm 0.46^{\mathrm{a}}$ & $0.71 \pm 0.03^{\mathrm{a}}$ & $1.56 \pm 0.15^{\mathrm{a}}$ \\
LH $(10 \mathrm{mmol} / \mathrm{L})$ & $2.78 \pm 0.37^{\mathrm{a}}$ & $0.72 \pm 0.03^{\mathrm{a}}$ & $1.23 \pm 0.08^{\mathrm{a}}$ \\
\hline
\end{tabular}


Table 2: mRNA expression levels of genes related to osteogenic differentiation amongst the groups (mean \pm SD)

\begin{tabular}{lcccc}
\hline Group & ALP mRNA & Col1-a mRNA & Run×2 mRNA & Osterix mRNA \\
\hline Control & $1.00 \pm 0.01$ & $1.00 \pm 0.03$ & $1.00 \pm 0.01$ & $1.02 \pm 0.02$ \\
LH $0.1 \mathrm{mmol} / \mathrm{L}$ & $1.78 \pm 0.25$ & $1.18 \pm 0.13$ & $1.15 \pm 0.21$ & $2.01 \pm 0.09$ \\
LH $1 \mathrm{mmol} / \mathrm{L}$ & $2.04 \pm 0.56^{\mathrm{a}}$ & $1.85 \pm 0.24^{\mathrm{a}}$ & $1.95 \pm 0.22^{\mathrm{a}}$ & $3.62 \pm 1.25^{\mathrm{a}}$ \\
LH $10 \mathrm{mmol} / \mathrm{L}$ & $4.81 \pm 0.45^{\mathrm{a}}$ & $1.93 \pm 0.25^{\mathrm{a}}$ & $2.01 \pm 0.26^{\mathrm{a}}$ & $4.59 \pm 1.31^{\mathrm{a}}$ \\
\hline
\end{tabular}

${ }^{a} p<0.05$, compared with control group

\section{DISCUSSION}

Osteoporosis occurs mostly in elderly people aged over 60 years, with an incidence of about $23 \%$. It is a chronic disease that seriously threatens the health of patients. Postmenopausal osteoporosis, a form of primary osteoporosis, is caused by a cliff-like decrease in the release of estrogen, leading to differentiation of proliferating cells, impairment of differentiation of osteoblasts, and ultimately osteoblast death. Previous studies have shown that bisphosphonates inhibit the differentiation and activity of osteoclasts. Since then, clinical scholars have focused on the therapeutic effect of traditional Chinese medicine on osteoporosis [8].

In the past, LH was used mostly in the treatment of gynecological diseases, and it significantly mitigates postpartum symptoms in women. Latest research reports indicate that $\mathrm{LH}$ plays a vital role in the treatment of cardiovascular and cerebrovascular diseases [9]. Orthopedicsrelated studies have reported that $\mathrm{LH}$ increased estrogen levels in a rat model of incomplete abortion. In addition, it reduced the differentiation and activity of osteoclasts, and mitigated reduction in bone mineral density [10]. However, the effect of LH on the differentiation activity of osteoblasts, and the mechanisms involved, were not hitherto clearly understood. This prompted the present study.

Many research reports have confirmed that the classic $W n t / \beta$-catenin route is involved in bone metabolism and related mechanisms. For example, it is closely related to the osteogenic differentiation process, and to other processes such as bone transformation in mesenchymal stem cells [11]. The Wnt factor binds to frizzled protein receptor and low-density lipoprotein receptor-related receptors on the surface of osteoblasts, and activates scatter protein 2 in osteoblasts. In this state, it can block the composition of GSK-3 $\beta$, Axin, and APC. Trimers also cause phosphorylation of GSK-3 $\beta$, which in turn affects the production of trimeric complexes [12]. Unphosphorylated $\beta$-catenin content is increased in osteoblasts, and it is then transferred to the nucleus where it interacts with $\mathrm{T}$ cell factor/lymphocyte enhancer factor, resulting in regulation of the expressions of target genes.

Studies have shown that ALP, Run $\times 2$, and osteoprotective factors regulate osteogenic differentiation-related genes [13]. The nuclear transduction of classic Wnt signaling pathway from the membrane takes a very short time, and it is very important in fracture and bone formation. Another report showed that direct phosphorylation of GSK-3 $\beta$ significantly increases the activity of Run $\times 2$ [14]. Alkaline phosphatase (ALP) and Osterix are important markers of osteoblast differentiation. Although ALP is a ubiquitous enzyme in humans, it occupies an important position in bone formation and bone mineralization. In addition, ALP is used as an important marker of bone metabolism in postmenopausal women [15].

The results of this study showed that ALP levels and the number of calcified nodules in cells treated with $\mathrm{LH}$ doses of 1 and $10 \mu \mathrm{mmol} / \mathrm{L}$ were significantly higher than the corresponding values in untreated control cells. These findings suggest that the medium and high doses of $\mathrm{LH}$ enhance ALP secretion and improve the production of bone mineralization nodules. The expression levels of LRP5 and $\beta$-catenin mRNA in cells exposed to $\mathrm{LH}$ doses of 1 and 10 $\mu \mathrm{mmol} / \mathrm{L}$ were markedly higher than control cell values, while mRNA levels of GSK-3 $\beta$ were significantly lower than the corresponding levels in control cells.

The mRNA expression levels of ALP, Col1- $\alpha$, Run $\times 2$ and Osterix in cells treated with $\mathrm{LH}$ doses of 1 and $10 \mu \mathrm{mmol} / \mathrm{L}$ were significantly higher than those in control cells. This suggests that $\mathrm{LH}$ activated the $\mathrm{Wnt} / \beta$-catenin route and increased levels of $\beta$-catenin and Run $\times 2$, which ultimately led to osteogenic differentiation.

\section{CONCLUSION}

Leonurusine hydrochloride promotes osteogenic differentiation through a mechanism associated with stimulation of $\mathrm{Wnt} / \beta$-catenin pathway and upregulation of the expression of Run $\times 2$. This provides a new choice for the preventive treatment of osteoporosis. 


\section{DECLARATIONS}

\section{Acknowledgement}

This study was supported by Scientific Research Project of Traditional Chinese Medicine in Jiangxi Province (no. 2019A101)

\section{Conflict of interest}

No conflict of interest is associated with this work.

\section{Contribution of authors}

This study was done by the authors named in this article, and the authors accept all liabilities resulting from claims which relate to this article and its contents. The study was conceived and designed by Yu Cai. Xiaobo Chen, Xiaoyu Lai, Xiaoyon Sun, Maoyuan Wang and Yu Cai collected and analyzed the data, while Xiaobo Chen wrote the manuscript. All authors read and approved the manuscript for publication.

\section{Open Access}

This is an Open Access article that uses a funding model which does not charge readers or their institutions for access and distributed under the terms of the Creative Commons Attribution License (http://creativecommons.org/licenses/by/ 4.0) and the Budapest Open Access Initiative (http://www.budapestopenaccessinitiative.org/rea d), which permit unrestricted use, distribution, and reproduction in any medium, provided the original work is properly credited.

\section{REFERENCES}

1. Binkley N, Krueger D, Papp AE. Multiple vertebral fractures following osteoporosis treatment discontinuation: a case-report after long-term Odanacatib. Osteoporosis Int 2018; 29(4): 1-4.

2. Brita S, Hege B, Lora G, Are HP, Astrid B. Effect of a resistance and balance exercise programme for women with osteoporosis and vertebral fracture: study protocol for a randomized controlled trial. BMC Musculoskel Dis 2018; 19(1): 100-105.

3. Hongyang $Z$, Xiaojuan $S$, Long $W$, Xiaojie $L$, Chao Z, Bo $G$, Xiaolong $X$, Xisheng $L$, Jinpeng $W$, Yangjing $L$, et al. Intramembranous ossification and endochondral ossification are impaired differently between glucocorticoid-induced osteoporosis and estrogen deficiency-induced osteoporosis. Sci Rep-UK 2018; 8(1): 3867-3872.

4. Rizzoli R, Biver E, Bonjour JP, Coxam V, Goltzman D, Kanis JA, Lappe J, Rejnmark L, Sahni S, Weaver C, et al. Benefits and safety of dietary protein for bone healthan expert consensus paper endorsed by the European society for clinical aspects of osteoporosis, osteoarthritis and musculoskeletal diseases and by the international osteoporosis foundation. Maturitas 2018; 79(1): 122132.

5. Feng-Lai $Y$, Rui-Sheng $X$, Dong-Lin J, Xing-Long $H$, QiangSu C, JinXia L. Leonurine hydrochloride inhibits osteoclastogenesis and prevents osteoporosis associated with estrogen deficiency by inhibiting the NF$K B$ and PI3K/Akt signaling pathways. Bone 2018; 75: 128-137.

6. Xia L, Feng-Lai Y, Yi-Qing Z, Fei-Hu C, Wei-Guo L, Cheng-Wan $L$, Jian-Ping $L$. Effects of leonurine hydrochloride on medically induced incomplete abortion in early pregnancy rats. Eur Journal Obstet Gynecol \& Reprod Biol 2016; 159(2): 0-380.

7. Jie C, Dawei G, Wanli M, Dali H, Wei D, Hongliang G, Yi Zhang. A feedback loop consisting of RUNX2/LncRNAPVT1/miR-455 is involved in the progression of colorectal cancer. Am J Cancer Res 2018; 8(3): 538550.

8. Jinmei $D$, Dongmei $C$, Suming J, Enjing $C$, Xiuzhen $C$, Yanbing $L$. Sequential treatment reduces the acute phases of adverse effect of zoledronic acid in first time users. Open J Prev Med 2018; 08(7): 189-205.

9. Xia L, Feng-Lai Y, Yi-Qing Z, Wei-Guo L, Cheng-Wan L, Chun-Hui $H$. Effect of leonurine hydrochloride on endothelin and the endothelin receptor-mediated signal pathway in medically-induced incomplete abortion in rats. Eur J Obstet Gynecol Reprod Biol, 2018, 169(2): 299-303.

10. Li Y, Gang L, Kexun L, Yanjie Q, Baojun Z, Xiaoqing Z, Yan L, Yunxia S, Xin-Li G. Dietary leonurine hydrochloride supplementation attenuates lipopolysaccharide challenge-induced intestinal inflammation and barrier dysfunction by inhibiting the NF-KB/MAPK signaling pathway in broilers. J Ani Sci 2019(4): 4-11.

11. $Y u L, Y e Y$, Tianlong $W$, Li W, Xin W, Tiemin L, Yue S, Yawei $W$. Long non-coding RNA CCAL promotes hepatocellular carcinoma progression by regulating $A P$ $2 \alpha$ and Wnt/ $\beta$-catenin pathway. Int $J$ Biol Macromol 2018; 109: 424-434.

12. Wei-Ying L, Zhen Y. Qi S, Xi Y, Yang $H$, Hong $X$, Hui-Jie G, Li-Ming G, Jian-Ying $Y$, Min L, Hua T. miR-377-3p drives malignancy characteristics via upregulating GSK$3 \beta$ expression and activating NF-KB pathway in hCRC cells. J Cell Biochem 2018; 119(2): 2124-2134.

13. Naoaki S, Hiroko K, Yosuke A, Yuko H, Taku K, Michiko Y, Atsushi O, Takeyasu M, Tadaharu K, Kenji I. Application of hypoxic exposure combined with osteogenic induction for the enhancement of multiple osteoinductive capabilities in rat mesenchymal cells. Open J Stomatol 2018; 08(2): 53-69.

14. Ke-Tao D, Jia-Qin D, Xu-Guang $H$, Zhao-ping $L$, Cheng $P$, Ming-Sheng Z. Mir-214 regulates the human hair follicle stem cell proliferation and differentiation by

Trop J Pharm Res, January 2021; 20(1): 21 
targeting ezh2 and wnt/ $\beta$-catenin signaling way in vitro. Tissue Eng Regen Med 2018; 15: 341-350.

15. Panteghini M, Pagani F. Reference intervals for two bone-derived enzyme activities in serum: bone isoenzyme of alkaline phosphatase (ALP) and tartrateresistant acid phosphatase (TR-ACP). Clin Chem 2019; (1): $1-5$. 